\title{
U.S. Shrimp Market Integration
}

\author{
Frank Asche, ${ }^{1}$ Lori S. Bennear, ${ }^{2,3,4}$ Atle Oglend,${ }^{1}$ and Martin D. Smith ${ }^{2,4, *}$
}

1. Department of Industrial Economics, University of Stavanger, 4036 Stavanger, Norway

2. Nicholas School of the Environment, Duke University, Box 90328, Durham, NC 27701

3. Sanford School of Public Policy, Duke University

4. Department of Economics, Duke University

* Corresponding author.

Email: marsmith@duke.edu, ph: (919) 613-8028, fax: (919) 684-8071

\begin{abstract}
Recent supply shocks in the Gulf of Mexico-including hurricanes, the Deepwater Horizon oil spill, and the seasonal appearance of a large dead zone of low oxygen water (hypoxia)- have raised concerns about the economic viability of the U.S. shrimp fishery. The ability for U.S. shrimpers to mediate supply shocks through increased prices hinges on the degree of market integration, both among shrimp of different sizes classes and between U.S. wild caught shrimp and imported farmed shrimp. We use detailed data on shrimp prices by size class and import prices to conduct a co-integration analysis of market integration in the shrimp industry. We find significant evidence of market integration, suggesting that the law of one price holds for this industry. Hence, in the face of a supply shocks, prices do not rise and instead imports of foreign farmed fish increase.
\end{abstract}

JEL: Q22

Keywords: seafood trade, market integration, environmental shocks

Acknowledgments: Financial support for this research was provided by the National Oceanic and Atmospheric Administration Grant\# 2162501 and by the Research Council of Norway. The authors thank Jim Nance for providing the U.S. shrimp data and for helpful discussions. 


\title{
U.S. Shrimp Market Integration
}

\begin{abstract}
Recent supply shocks in the Gulf of Mexico-including hurricanes, the Deepwater Horizon oil spill, and the seasonal appearance of a large dead zone of low oxygen water (hypoxia) - have raised concerns about the economic viability of the U.S. shrimp fishery. The ability for U.S. shrimpers to mediate supply shocks through increased prices hinges on the degree of market integration, both among shrimp of different sizes classes and between U.S. wild caught shrimp and imported farmed shrimp. We use detailed data on shrimp prices by size class and import prices to conduct a co-integration analysis of market integration in the shrimp industry. We find significant evidence of market integration, suggesting that the law of one price holds for this industry. Hence, in the face of a supply shocks, prices do not rise and instead imports of foreign farmed fish increase.
\end{abstract}

JEL: Q22

Keywords: seafood trade, market integration, environmental shocks

\section{Introduction}

Shrimp is the world's most valuable seafood product, accounting for $17 \%$ of the global seafood trade in 2006 (FAO 2009). Although more than half of the world's shrimp are farmed now, significant wild shrimp fisheries remain in many parts of the world, including in the Gulf of Mexico and along the East Coast of the United States. Figure 1 depicts global shrimp production broken down by farmed and wild shrimp. Production of wild shrimp increased in recent decades but leveled off in 2003 at just over 3 million metric tons. Farmed shrimp production increased at even faster rates and reached a production of 3.5 million metric tons in 2009 for a combined global supply of over 6.6 million metric tons. This increased production has fueled an increased trade in shrimp. As for most farmed species, the markets in the EU, Japan and the U.S. have been the most targeted, since these are the markets with the highest willingness to pay.

Consumption of shrimp in the United States reflects the global surge in shrimp production. Shrimp ranked first in 2004 U.S. per capita seafood consumption at 4.2 pounds, nearly a 
pound more than the second ranked seafood category (canned tuna with 3.3 pounds per capita) (NRC 2007). In 2010, shrimp consumption remained high at 4.0 pounds per capita compared to 2.7 pounds per capita of canned tuna, and consumption of all fillets and steaks aggregated across species amounted to only 5.0 pounds per capita (National Marine Fisheries Service 2011). Much of this consumption comes from imported farm-raised shrimp, as the U.S. has developed into the world's largest shrimp import market (Anderson, 2003). In 1980, domestic shrimp had a $43 \%$ market share, but that share declined to $12 \%$ by 2001 (Mukherjee and Segerson 2011). In spite of the declining market share, the U.S. still maintains a large wild shrimp fishery with $80 \%$ caught in the Gulf of Mexico (Mukherjee and Segerson 2011). The U.S. domestic shrimp fishery has three main species: brown, pink and white shrimp, the largest being brown. Brown shrimp landings in the Gulf over the past decade ranged from 33,000 to 71,000 metric tons with landed value between $\$ 137$ million and $\$ 355$ million. For pink, landings ranged from 2,300 to 6,900 metric tons with landed value between $\$ 10$ million and \$39 million. For white, landings ranged from 37,000 to 67,000 metric tons with landed value between $\$ 141$ million and \$252 million . ${ }^{1}$

Understanding how integrated the markets for domestic wild-caught shrimp fisheries are with markets for farmed shrimp imports is important for several reasons. First, the rapid increase in farmed shrimp production coupled with large domestic wild-caught fisheries has created trade disputes in the EU and in the U.S. The U.S., for example, enacted trade restrictions on shrimp from a group of six named countries (all in Asia or Latin America) in 2004 after domestic fishermen filed anti-dumping complaints against several shrimp exporting countries (Keithly and Poudel, 2008). Second, diseases have been an issue for farmed shrimp. The reduced growth rates in farmed shrimp production in the 1990s can largely be attributed to the white spot disease (Anderson, 2003). Third, there are significant environmental shocks that

\footnotetext{
${ }^{1}$ http://www.st.nmfs.noaa.gov/st1/commercial/landings/annual_landings.html
} 
affect the supply of domestic wild-caught shrimp. For U.S. shrimp fishermen, hypoxia-most notably the seasonal dead zone in the Gulf of Mexico - has been a reoccurring phenomenon that potentially influences aggregation, production, and the size distribution of shrimp (Craig 2011; Huang, Smith, and Craig, 2010; Huang et al. 2011). Hurricanes Katrina and Rita caused significant shrimp supply disruptions through destruction of shrimp vessels and processing facilities (Buck 2005), while rising fuel prices are particularly costly for wild-caught shrimp because trawling is fuel-intensive (Ran, Keithly, Kazmierczak 2011), Moreover, costs of complying with the U.S. requirement for shrimp trawlers to use Turtle Excluder Devices decreased domestic supply (Mukherjee and Segerson 2011). The degree of market integration affects how these environmental and economic stressors affect prices. The impact of all of these stressors (trade, production costs, disease, and environmental) will have a strong impact on the price determination process if the markets are not integrated, while the impact will be weaker in a larger and more integrated shrimp market. The rationale is that consumers can substitute other species (or substitute across wild or farmed) if the supply of one species becomes scarce due to a production shock.

Despite being the world's most important aquaculture species and comparably significant global capture landings, there are relatively few studies shedding light on the price determination process for shrimp. Vinuya (2007) is an exception, indicating that there is a global market for farmed shrimp. We investigate the extent of the shrimp market by testing for market integration using prices. Time series analysis of market integration has been used for a number of seafood products in recent decades. It is particularly useful when there is a large number of products/markets of interest, as demand analysis in such cases is not feasible (Asche, Gordon and Hannesson, 2004). Time series analysis can also be a flexible approach by allowing tests across geographically distinct markets, different species, and different product forms. If prices are stationary, ordinary regression analysis can be used (Squires, 
Herrick Jr., and Hastie, 1989; Asche, Gordon and Hannesson, 2004). But if prices are nonstationary, cointegration analysis is the appropriate econometric tool. ${ }^{2}$

The paper is proceeds as follows. The data are described in Section 2. Section 3 contains a description of the time-series methods used for the empirical tests of market integration. Section 4 reports the results. Section 5 concludes with discussion and implications for the shrimp market.

\section{Data}

Our data set consists of monthly prices covering the period of June 1990 through December 2008. The prices of brown, pink and white shrimp by size are for the Gulf of Mexico shrimp fishery and are computed by aggregating daily landings values and quantities that are recorded in the NOAA's SHRCOM database. SHRCOM is the primary source of micro-data used for fisheries management in the Gulf of Mexico. The import prices are U.S. import prices from the U.S. Department of Commerce www.st.nmfs.noaa.gov/st1/trade).

Shrimp size is measured as the number of shrimp per pound. Hence, a higher number implies a smaller average size for the shrimp. In the raw data, prices are available for the three species in eight size categories for a total of 24 price time series. Figures 2 shows the prices by size class for brown shrimp. Price series for pink and white shrimp appear similar (Asche et al. 2011). In all cases, larger sizes are more valuable per pound, and there is substantial variation in the price level by size. However, the price development of the different sizes appears to follow a common trend. Within each species, price increases (decreases) for one size tend to

\footnotetext{
${ }^{2}$ Since most seafood prices are found to be nonstationary, cointegration is the most commonly used empirical tool to test for market integration (Gordon, Salvanes and Atkins, 1993; Bose and McIlgrom, 1996; Gordon and Hannesson, 1996; Asche, Bremnes and Wessells, 1999; Asche, 2001; Jaffry et al, 2001; Asche et al, 2005; Nielsen, 2005; Nielsen et al 2007; Norman-López and Asche, 2008; Nielsen, Smit and Guillen, 2009; NormanLópez, 2009).
} 
translate into price increases (decreases) for each of the other sizes. Visually, Figure 2 suggests market integration, which we formally test in Section 4.

To compare the price development of U.S. shrimp with imports, the different weight classes are aggregated to avoid the curse of dimensionality. ${ }^{3}$ This weighting is done by constructing a Fisher Price index for each of the three species. For imported shrimp, the category "shell-on frozen" is used. This category is the closest to the largest volumes for domestically produced shrimp because it is relatively unprocessed. In contrast, products like breaded shrimp or shrimp in frozen meals contain significant value added that could distort inferences about market integration.

Before conducting formal tests of market integration, the time series properties of the prices must be investigated. The results from Augmented Dickey-Fuller (ADF) tests are reported in Table 1. Nearly all of the individual size-based price series are nonstationary in levels but stationary in first differences. The exceptions are small brown shrimp and very large pink shrimp that appear stationary in levels. All indexed prices are nonstationary in levels but stationary in first differences. The price series are, accordingly, integrated of order one, and cointegration analysis is the appropriate tool. This finding is as expected and in line with what is found for most seafood prices.

\section{Methods $^{4}$}

Let $p_{1 t}$ be the price in one market and $p_{2 t}$ the price in another. The basic relationship of interest for investigating market integration using time-series price data is the following:

$$
\ln p_{1 t}=\alpha+\beta \ln p_{2 t},
$$

\footnotetext{
${ }^{3}$ Hendry (1995) provides a good discussion of the curse of dimensionality in time series analysis.

${ }^{4}$ This section largely follow Asche, Gordon and Hannesson (2004).
} 
where $\alpha$ is a constant term that captures differences in the levels of the prices and $\beta$ indicates the relationship between the prices. If $\beta=0$, there is no relationship between the prices, whereas if $\beta=1$ the prices are proportional. When prices are proportional, the relative price is stationary, a phenomenon known as the Law of One Price (LOP). If $\beta$ differs from zero but is not equal to one, there is a relationship between the prices, but the relative price is not constant. Equation (1) describes the situation when prices adjust immediately. However, there is often a dynamic adjustment pattern, which can be captured with lags of the two prices (Ravallion, 1986; Slade, 1986). Even when dynamics are introduced, the long-run relationship will have the same form as equation (1).

Since the late 1980s economists have known that traditional econometric tools cannot be used when price series are non-stationary; standard statistical theory for inference breaks down in these situations (Engle and Granger, 1987). Cointegration analysis is then the appropriate tool to infer causal long-run relationships between non-stationary time series. There are two common approaches to test for cointegration: the single equation-based Engle and Granger test and the Johansen test (Johansen, 1988). Given that the price series are nonstationary and integrated of the same order, the Engle and Granger test is performed by estimating equation (1) and testing whether the residuals are stationary. Stationary residuals indicate that the two price series are cointegrated.

The Johansen test is appropriate for a system of prices, and accordingly allows for more than one long-run relationships. Moreover, it allows for hypothesis testing on the parameters in the cointegration vector and exogeneity tests. The Johansen method is based on a vector autoregressive error correction model (VECM). With a vector, $\boldsymbol{P}_{t}$, containing the $n$ prices., to test for cointegration the system can be written as 


$$
\Delta P_{t}=\sum_{i=1}^{k-1} \Gamma_{i} \Delta P_{t-i}+\Pi_{k} P_{t-k}+\mu+e_{t}
$$

The matrix $\Pi$ contains the parameters in the long-run relationships (the cointegration vectors). Given $r$ cointegrating vectors, one can factorize $\Pi_{k}=\alpha \beta^{\prime}$, where both $\alpha$ and $\beta$ are $(n \times r)$ matrices. The $\beta$-matrix contains the cointegrating vectors and $\alpha$ the adjustment parameters. We use the trace test to determine the rank of $\Pi$. Tests with respect to the structural relationship between the prices (markets) are tests of restrictions on the parameters in the cointegrating vectors, $\beta$. Information about the existence of a central market is formally conducted through exogeneity tests on the $\alpha$ coefficients and through examination of the integrating factors.

To illustrate, consider the case with only two price series, A and B. Assume that the two price series are nonstationary but cointegrated and that one lag is sufficient to capture the dynamics. The price relationships (suppressing the error terms) can be represented as

$$
\left[\begin{array}{l}
\Delta p_{t}^{A} \\
\Delta p_{t}^{B}
\end{array}\right]=\left[\begin{array}{l}
a_{1} \\
a_{2}
\end{array}\right]\left[\begin{array}{ll}
b_{1} & b_{2}
\end{array}\right]\left[\begin{array}{l}
p_{t-1}^{A} \\
p_{t-1}^{B}
\end{array}\right]
$$

If $b_{1}=-b_{2}$, the prices are proportional and the LOP holds. Usually, $b_{1}$ is normalized, so that the null hypothesis is $b_{2}=-1$. The parameters $a_{i}$ measure the impact of deviations from the long-run relationship and is normally denoted as the adjustment speed or factor loadings. In a system with $n$ price series and $r$ stochastic trends, there can be at most $r$ exogenous variables (Johansen and Juselius 1994). With the structure expected in efficiently functioning commodity markets, $n-1$ cointegrating vectors and one stochastic trend are expected (Asche, Bremnes and Wessells, 1999; Gonzalez-Rivera and Helfand, 2001).

\section{Empirical Results}


The sheer number of prices in the different shrimp size categories and species makes it virtually impossible to investigate the degree of market integration in one large system due to the curse of dimensionality. Moreover, Asche and Guttormsen (2001) note that prices for different weight classes are likely to be proportional, and if that is the case, they can be aggregated using the Generalized Composite Commodity Theorem of Lewbel (1996). We thus commence our analysis by testing for market integration for each of the three species where prices by size are available. We then investigate the relationships among the three species and imports.

For the separate species, the most interesting issue is whether the market is fully integrated or whether there exist different price determination processes by size. Supply shocks could affect different size classes differently due to spatio-temporal dynamics of the fishery and individual species life histories. Separate markets for each size would suggest that shocks that affect one size class would not propagate through to other size classes. This outcome, in turn, would affect the level of price compensation in the affected market. We thus use Engle and Granger tests for the size classes within each species and start out by imposing proportionality, i.e. $\beta$ $=1$ in equation (1). If this hypothesis is rejected, we continue to test for cointegration without this restriction to distinguish the case of imperfect market integration from no market integration.

The results of the Engle and Granger test are reported in Table 2. For nearly all price pairs, the null hypothesis of nonstationarity is rejected. The only exceptions are for the smallest size classes that constitute small shares of the total landings. Hence, we conclude that for all the three species, there is strong evidence of a common price determination process and that the prices move proportionally over time. This conclusion implies that one can construct an aggregate price for each species. 
To investigate the relationships among the prices of the three species and the import price, a Johansen test is used. Here we used the indexed prices depicted in Figure 3. The number of lags is chosen using the AIC and is found to be 14. A set of dummies is included to account for seasonality. The likelihood ratio test of Johansen and Juselius (1991) indicates that the constant term should be included in the cointegrating vectors.

The cointegration tests are reported in Table 3 . The results indicate that the system with four prices contains three cointegrating vectors and accordingly one common stochastic trend. This result is very robust with respect to model specification.

Normalized into bivariate relationships, the $\beta$ matrix containing the cointegrating vectors is given as

$$
\beta=\left[\begin{array}{ccc}
1 & 0 & 0 \\
0 & 1 & 0 \\
0 & 0 & 1 \\
-1.113 & -0.990 & -1.124 \\
-0.000 & -0.000 & -0.001
\end{array}\right]
$$

The $b$ parameters are all relatively close to one, indicating that the prices are close to proportional and the Law of One Price approximately holds. A test for this hypothesis is distributed as $\chi^{2}(3)$, and gives a test statistic of 4.595 . With a $p$-value of 0.204 , this hypothesis accordingly is not rejected.

Trade restrictions on some named countries that are introduced to protect domestic producers must influence the relationship between the domestic prices and the import price if they are to have any effect. This can be tested by testing for structural breaks in the price relationships (Asche, 2001). We do not find any evidence of any structural breaks in the relationships as a test for a break at January 2000 gives a $p$-value of 0.720 and a test of a structural break in January 2005 gives a $p$-value of 0.803 . This supports the conclusion of Keithly and Poudel 
(2008) who concluded that the trade restrictions primarily led to a reallocation of trade patterns, with little benefit to domestic producers.

\section{Discussion}

Using detailed monthly price data for shrimp of various sizes we find significant evidence of integration in the U.S. shrimp market. We test for proportionality in relative prices using all possible price-pairs for different size classes, suggesting a common price determination process and that the prices move proportionally over time.

We then construct an aggregate price index for each of three species of domestic wild-caught shrimp and test for market integration between wild-caught shrimp and imports of farmed shrimp. We again find significant evidence of market integration.

The degree of market integration, both among size classes and across farmed and wild-caught shrimp has important implications for policy. First, in order for trade restrictions on imported shrimp from named countries to protect domestic producers, these restrictions must influence the relationship between the domestic prices and the import price. Market integration suggests that this does not occur and trade restrictions act a as a shift in the type of imports, for example by shifting to imports from non-named countries or of non-restricted shrimp (i.e., processed shrimp), rather than helping domestic producers.

Second, if farmed shrimp are subject to supply shocks from disease, market integration implies that the domestic wild-caught fishery can replace supply from imports. The domestic industry would benefit through expanded production but not through higher prices. Given the wide range of domestic production and the influence of cost factors on supply, there is likely room for such expansion. However, a caveat is in order. A major global shock to farmed shrimp production that exceeds the magnitude of changes we observe in sample could lead to the break down of market integration. 
Finally, market integration has significant implications for how domestic wild-shrimp fisherman can respond to certain environmental supply shocks. In North Carolina (a much smaller market than Gulf of Mexico), there is evidence that hypoxia has decreased shrimp production in the range of $13 \%$ but has not increased prices (Huang, Smith, and Craig 2010; Huang et al. 2011). In the much larger Gulf of Mexico, there is emerging evidence that hypoxia decreases the supply of large shrimp and increases the supply of smaller shrimp, likely as a result of aggregation on the edge of hypoxic areas (Bennear, Kociolek, and Smith 2011; Craig 2011). Market integration suggests that the decreased supply of large shrimp cannot be offset by an increase in price. Rather, imports of larger farmed shrimp will increase to satisfy demand. Similarly, domestic supply shocks from hurricanes, oil spills, or fuel price spikes cannot be offset by price increases. In particular, market integration suggests that the economic losses from a significant decrease in 2010 domestic shrimp production - assuming this decrease was caused by the Deepwater Horizon oil spill - was not likely offset by a price increase. Market integration thus has important implications for the long-run economic viability of the U.S. shrimp fishery. The losses from supply shocks are more consequential for producers, and the various shocks are additive as economic challenges to the fishery. But U.S. shrimp consumers are essentially unharmed. Market integration also implies that regional demand shocks (positive or negative) are felt by the entire industry, but their effects are dampened relative to how they would be felt in particular regions if markets were not integrated.

One important caveat to our findings is that we have examined market integration in a period (1990-2008) when shrimp imports have grown dramatically. While we find significant market integration during this period, this integration could be recent and might not be found if looking at subsets of the time domain. That is, it may be that earlier portions of the time domain did not have market integration, and the implications for supply shocks during these 
times varied. Hypoxia has been documented in the Gulf for two decades, though detailed data are only available since the late 1990s. It may be that hypoxia had some ability to influence prices in the past but no longer can due to the massive increase in imported shrimp.

A second caveat is to consider how the domestic wild-caught shrimp industry will react to the many economic stressors it faces. Currently, there is growing interest amongst American consumers in buying local food and wild-caught seafood in particular. The domestic shrimp industry is attempting to capitalize on this interest.$^{5}$ It remains to be seen whether domestic wild-caught shrimp producers will successfully segment the market and undo the market integration with imported farmed shrimp.

\footnotetext{
${ }^{5}$ http://www.wildamericanshrimp.com/main.html
} 


\section{References}

Anderson, J.L. 2003. The International Seafood Trade. Cambridge: Woodhead Publishing.

Asche, F. 2001. Testing the effect of an anti-dumping duty: The US salmon market. Empirical Economics 26(2):343-55.

Asche, F., H. Bremnes and C.R. Wessells. 1999. Product Aggregation, Market Integration and Relationships Between Prices: An Application to World Salmon Markets. American Journal of Agricultural Economics 81(August):568-81.

Asche, F., D.V. Gordon and R. Hannesson. 2004. Tests for Market Integration and the Law of One Price: The Market for Whitefish in France. Marine Resource Economics 19(2):195-210.

Asche, F. and A.G. Guttormsen. 2001. Patterns in the Relative Price for Different Sizes of Farmed Fish. Marine Resource Economics 16(3):235-47.

Asche, F., et al. 2005. Competition between farmed and wild salmon: The Japanese salmon market. Agricultural Economics 33:333-40.

Asche, F., L.S. Bennear, A. Oglend, and M.D. Smith. 2011. U.S. Shrimp Market Integration. The Duke Environmental Economics Working Paper Series. Working Paper EE 11-09. Durham, NC.

Bennear, L.S., E. Kociolek and M.D. Smith. 2011. Estimating the effect of hypoxia on the Gulf Coast shrimp fishery. Selected Paper, AERE Summer Conference Seattle, WA,

Bose, S. and A. McIlgrom. 1996. Substitutability Among Species in the Japanese Tuna Market: A Cointegration Analysis. Marine Resource Economics 11(Fall):143-56.

Buck, E.H. (2005). Hurricanes Katrina and Rita: Fishing and Aquaculture Industries Damage and Recovery. CRS Report for Congress, RS22241. Washington DC, Congressional Research Service.

Craig, J.K. 2011. Aggregation on the edge: Effects of hypoxia avoidance on the spatial distribution of brown shrimp and demersal fishes in the northern Gulf of Mexico.

Forthcoming in Marine Ecology Progress Series.

Engle, R.F. and C.W.J. Granger. 1987. Co-integration and Error Correction: Representation, Estimation and Testing. Econometrica 55(March):251-76.

FAO. 2009. The state of world fisheries and aquaculture 2008. Rome: FAO.

Gonzales-Rivera, G. and S.M. Helfand. 2001. The Extent, Pattern, and Degree of Market Integration: A Multivariate Approach for the Brazilian Rice Market. American Journal of Agricultural Economics 83(3):576-92.

Gordon, D.V. and R. Hannesson. 1996. On Prices of Fresh and Frozen Cod. Marine Resource Economics 11(Winter):223-38. 
Gordon, D.V., K.G. Salvanes and F. Atkins. 1993. A Fish Is a Fish Is a Fish: Testing for Market Linkage on the Paris Fish Market. Marine Resource Economics 8(Winter):331-43.

Hendry, D.F. 1995. Dynamic Econometrics. Oxford: Oxford University Press.

Huang, L., L.A.B. Nichols, J.K. Craig and M.D. Smith 2012. Measuring Welfare Losses from Hypoxia: The Case of North Carolina Brown Shrimp. forthcoming. Marine Resource Economics.

Huang, L., M.D. Smith and J.K. Craig. 2010. Quantifying the Economic Effects of Hypoxia on a Fishery for Brown Shrimp Farfantepenaeus aztecus. Marine and Coastal Fisheries: Dynamics, Management, and Ecosystem Science 2:232-48.

Jaffry, S., et al. 2000. Price interactions between salmon and wild caught fish species on the Spanish market. Aquaculture Economics and Management 4:157-68.

Johansen, S. 1988. Statistical Analysis of Cointegration Vectors. Journal of Economic Dynamics and Control 12:231-54.

---. 1991. Estimation and Hypothesis Testing of Cointegration Vectors in Gaussian Autoregressive Models. Econometrica 59:1551-80.

Keithly Jr., W.R. and P. Poudel. 2008. The Southeast U.S.A. Shrimp Industry: Issues Related to Trade and Antidumping Duties. Marine Resource Economics 23(4):439-63.

Lewbel, A. 1996. Aggregation without Separability: A Generalized Composite Commodity Theorem. American Economic Review 86(June):524-61.

Mukherjee, Z. and K. Segerson. 2011. Turtle Excluder Device Regulation and Shrimp Harvest: The Role of Behavioral and Market Responses. Marine Resource Economics 26(2):173-89.

National Marine Fisheries Service. 2011. Fisheries of the United States 2010. Silver Spring, MD: U.S. Department of Commerce.

Nielsen, M. 2005. Price Formation and Market Integration on the European First-hand Market for Whitefish. Marine Resource Economics 20(2):185-202.

Nielsen, M., et al. 2007. Market Integration of Farmed Trout in Germany. Marine Resource Economics 22:195-213.

Nielsen, M., J. Smit and J. Guillen. 2009. Market Integration of Fish in Europe. Journal of Agricultural Economics 60(2):367-85.

Norman-López, A. 2009. Competition between different Wild and Farmed Species: The US Tilapia Market. Marine Resource Economics 24:237-52.

Norman-López, A. and F. Asche. 2008. Competition between imported Tilapia and US catfish in the US market. Marine Resource Economics 23(2):199-214. 
Ran, T., W.R. Keithly Jr. and R.F. Kazmierczak. 2011. Location Choice Behavior of Gulf of Mexico Shrimpers under Dynamic Economic Conditions. Journal of Agricultural and Applied Economics 43(1):29-44.

Ravallion, M. 1986. Testing Market Integration. American Journal of Agricultural Economics 68(1):102-9.

Slade, M.E. 1986. Exogeneity Test of Market Boundaries Applied to Petroleum Products. Journal of Industrial Economics 34:291-304.

Squires, D., S.F. Herrick Jr. and J. Hastie. 1989. Integration of Japanese and United States Sablefish Markets. Fishery Bulletin 87(2).

Vinuya, F.D. 2007. Testing for Market Integration and the Law of One Price in World Shrimp Markets. Aquaculture Economics and Management 11(3):243-65. 


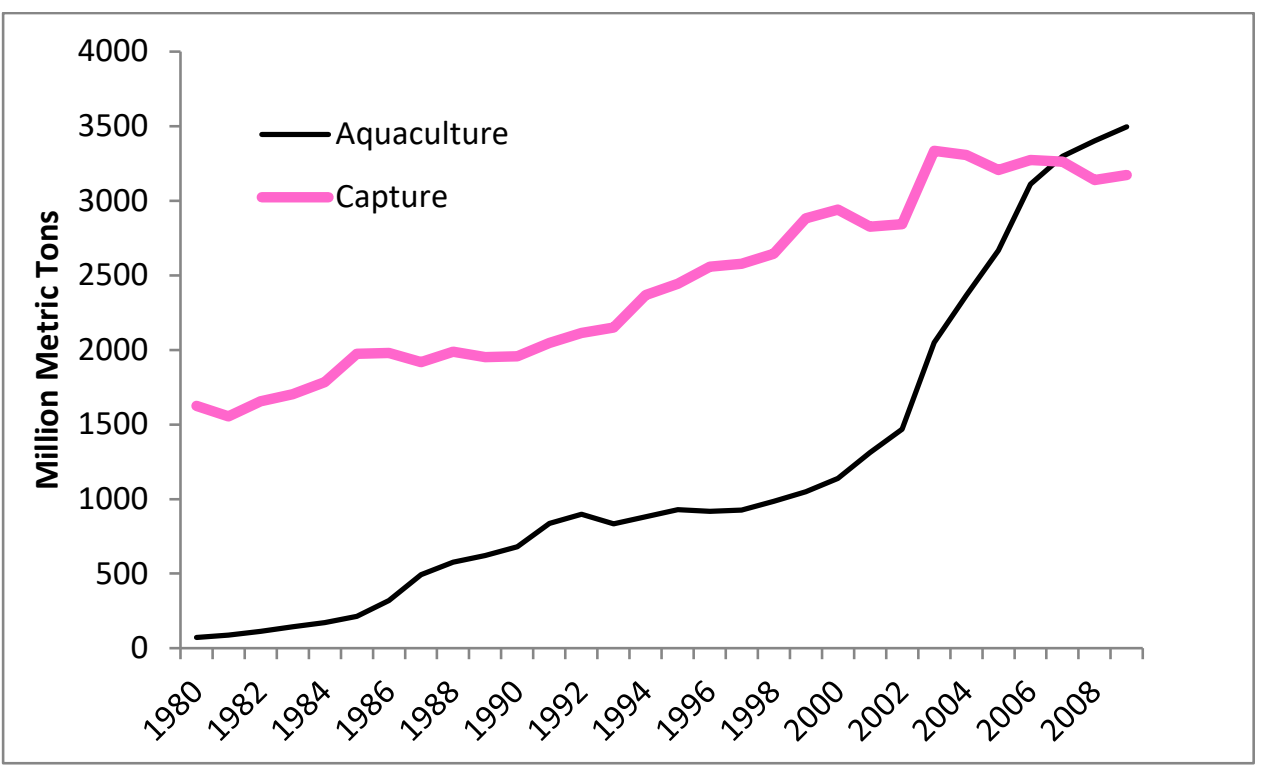

Figure 1. Global shrimp production by production method 


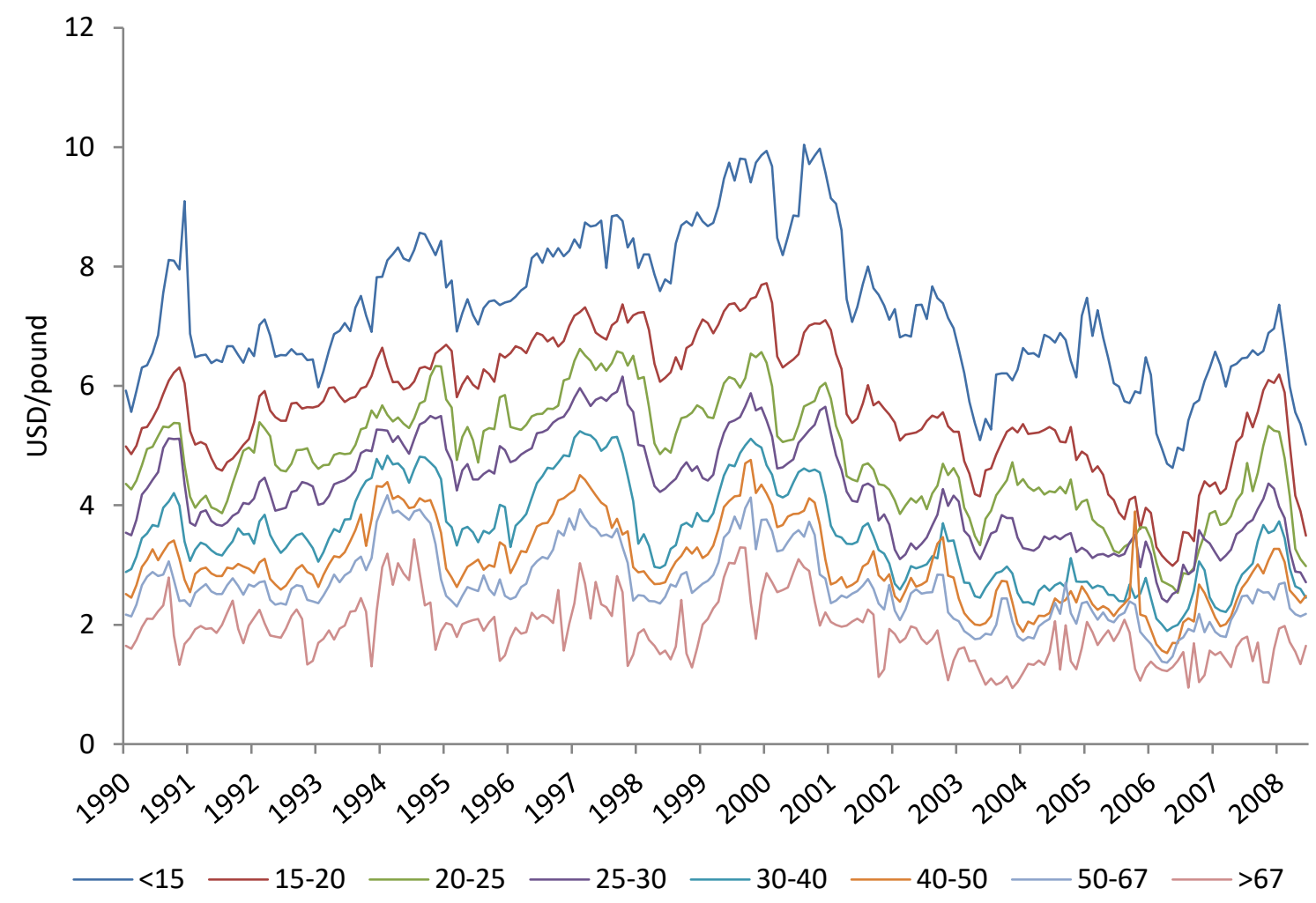

Figure 2. Monthly Prices of Gulf of Mexico Brown Shrimp in Different Size Classes 


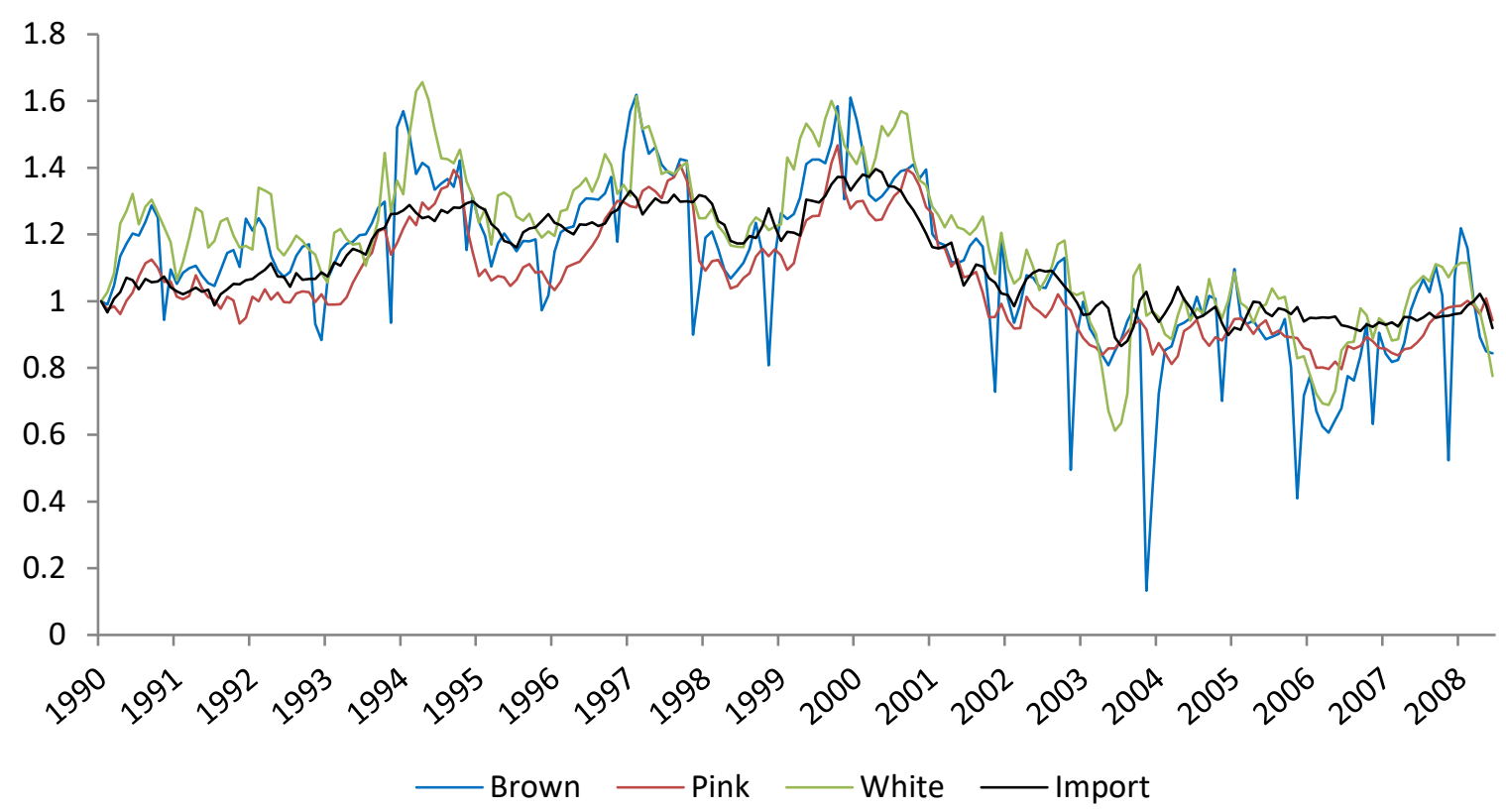

Figure 3. Monthly Fisher Index Prices and Import Prices for Shrimp 
TABLE 1. Augmented Dickey Fuller Unit Root Tests Shrimp Series

\begin{tabular}{|c|c|c|c|c|c|}
\hline \multirow[b]{2}{*}{ Series } & \multirow[b]{2}{*}{ Weight Class } & \multicolumn{2}{|c|}{ Level } & \multicolumn{2}{|c|}{ 1st Difference } \\
\hline & & Constant & Trend & Constant & Trend \\
\hline \multirow[t]{8}{*}{ Brown } & $<15$ & -1.583 & -2.217 & $-4.245 * *$ & $-4.342 * *$ \\
\hline & $15-20$ & -1.176 & -2.398 & $-4.453 * *$ & $-4.632 * *$ \\
\hline & $20-25$ & -1.636 & -2.853 & $-6.546^{* *}$ & $-7.805 * *$ \\
\hline & $25-30$ & -1.069 & -2.768 & $-7.302 * *$ & $-7.382 * *$ \\
\hline & $30-40$ & -1.821 & -3.312 & $-11.14 * *$ & $-11.14 * *$ \\
\hline & $40-50$ & -2.540 & $-3.523^{*}$ & $-3.595 * *$ & $-3.588 *$ \\
\hline & $50-67$ & -2.466 & -3.138 & $-13.51 * *$ & $-13.49 * *$ \\
\hline & $>67$ & -2.802 & $-3.790 *$ & $-3.740 * *$ & $-4.321 * *$ \\
\hline \multirow[t]{8}{*}{ Pink } & $<15$ & $-4.672 * *$ & $-4.753 * *$ & $-7.707 * *$ & $-7.689 * *$ \\
\hline & $15-20$ & -2.053 & -2.081 & $-11.62 * *$ & $-11.59 * *$ \\
\hline & $20-25$ & -2.199 & -2.591 & $-16.02 * *$ & $-16.00 * *$ \\
\hline & $25-30$ & -1.720 & -2.238 & $-15.86^{* *}$ & $-15.84 * *$ \\
\hline & $30-40$ & -1.956 & -2.359 & $-14.44 * *$ & $-14.42 * *$ \\
\hline & $40-50$ & -2.478 & -2.466 & $-4.847 * *$ & $-4.861 * *$ \\
\hline & $50-67$ & -2.113 & -2.680 & $-9.537 * *$ & $-9.519 * *$ \\
\hline & $>67$ & $-2.965^{*}$ & $-3.577 *$ & $-7.519 * *$ & $-7.611 * *$ \\
\hline \multirow[t]{8}{*}{ White } & $<15$ & -1.217 & -2.116 & $-6.897 * *$ & $-6.512^{* *}$ \\
\hline & $15-20$ & -0.7487 & -2.014 & $-3.756 * *$ & $-3.884 *$ \\
\hline & $20-25$ & -1.767 & -3.107 & $-9.597 * *$ & $-9.696 * *$ \\
\hline & $25-30$ & -1.207 & -2.441 & $-4.067 * *$ & $-4.113 * *$ \\
\hline & $30-40$ & -1.851 & -3.217 & $-4.394 * *$ & $-4.472 * *$ \\
\hline & $40-50$ & -1.803 & -2.848 & $-4.019 * *$ & $-4.040 * *$ \\
\hline & $50-67$ & -2.546 & -3.384 & $-7.075 * *$ & $-10.63 * *$ \\
\hline & $>67$ & -2.368 & -3.350 & $-4.266 * *$ & $-4.279 * *$ \\
\hline Brown Fisher & - & -2.091 & -3.242 & $-4.579 * *$ & $-4.038^{* *}$ \\
\hline Pink Fisher & - & -2.069 & -2.678 & $-11.35 * *$ & $-11.33 * *$ \\
\hline White Fisher & - & -1.311 & -2.385 & $-4.360 * *$ & $-4.399 * *$ \\
\hline Import Fisher & - & -1.350 & -2.469 & $-4.867 * *$ & $-7.143^{* *}$ \\
\hline
\end{tabular}


TABLE 2. Cointegration tests on spreads of species by weightclass

\begin{tabular}{|c|c|c|c|c|c|c|c|c|}
\hline Species & Spread & ADF & Spread & ADF & Spread & ADF & Spread & ADF \\
\hline \multirow[t]{7}{*}{ Brown } & $15-1520$ & $-4.884 * *$ & $1520-2530$ & $-5.467 * *$ & $2025-3040$ & $-5.488 * *$ & $2530-67$ & $-4.294 * *$ \\
\hline & $15-2025$ & $-4.494 * *$ & $1520-2025$ & $-4.941 * *$ & $2025-4050$ & $-5.089 * *$ & $3040-4050$ & $-8.601 * *$ \\
\hline & $15-2530$ & $-3.915^{*}$ & $1520-3040$ & $-5.906 * *$ & $2025-5060$ & $-5.015 * *$ & $3040-5060$ & $-7.010 * *$ \\
\hline & $15-3040$ & $-4.601 * *$ & $1520-4050$ & $-4.800 * *$ & $2025-67$ & $-4.199 * *$ & $3040-67$ & -3.275 \\
\hline & $15-4050$ & $-4.336 * *$ & $1520-5067$ & $-4.491 * *$ & $2530-3040$ & $-4.389 * *$ & $4050-5060$ & -3.240 \\
\hline & $15-5067$ & $-3.862 *$ & $1520-67$ & $-4.580 * *$ & $2530-4050$ & $-4.439 * *$ & $4050-67$ & -3.206 \\
\hline & $15-67$ & $-3.996 *$ & $2025-2530$ & $-5.265 * *$ & $2530-5060$ & $-4.321 * *$ & $5060-67$ & -3.159 \\
\hline \multirow[t]{7}{*}{ Pink } & $15-1520$ & $-7.484 * *$ & $1520-2530$ & $-4.650 * *$ & $2025-3040$ & $-5.285^{* *}$ & $2530-67$ & $-6.431 * *$ \\
\hline & $15-2025$ & $-4.561 * *$ & $1520-2025$ & $-3.788^{*}$ & $2025-4050$ & $-4.442 * *$ & $3040-4050$ & $-4.344 * *$ \\
\hline & $15-2530$ & $-7.773 * *$ & $1520-3040$ & $-6.025 * *$ & $2025-5060$ & $-3.600 *$ & $3040-5060$ & $-4.368 * *$ \\
\hline & $15-3040$ & $-6.153 * *$ & $1520-4050$ & $-5.403 * *$ & $2025-67$ & $-5.970 * *$ & $3040-67$ & $-7.338 * *$ \\
\hline & $15-4050$ & $-6.507 * *$ & $1520-5067$ & $-4.445^{* *}$ & $2530-3040$ & $-5.102 * *$ & $4050-5060$ & $-5.193 * *$ \\
\hline & $15-5067$ & $-5.569 * *$ & $1520-67$ & $-5.221 * *$ & $2530-4050$ & $-4.670 * *$ & $4050-67$ & $-6.635 * *$ \\
\hline & $15-67$ & $-7.130 * *$ & $2025-2530$ & $-5.314 * *$ & $2530-5060$ & $-4.493 * *$ & $5060-67$ & $-9.303 * *$ \\
\hline \multirow[t]{7}{*}{ White } & $15-1520$ & $-4.027 * *$ & $1520-2530$ & $-3.526^{*}$ & $2025-3040$ & $-5.050^{* *}$ & $2530-67$ & $-5.267 * *$ \\
\hline & $15-2025$ & $-3.478 *$ & $1520-2025$ & $-3.458 *$ & $2025-4050$ & $-4.361 * *$ & $3040-4050$ & $-5.807 * *$ \\
\hline & $15-2530$ & $-3.770 *$ & $1520-3040$ & $-4.159 * *$ & $2025-5060$ & $-4.210 * *$ & $3040-5060$ & $-6.085 * *$ \\
\hline & $15-3040$ & $-4.043 * *$ & $1520-4050$ & $-4.030 * *$ & $2025-67$ & $-3.676^{*}$ & $3040-67$ & $-5.998 * *$ \\
\hline & $15-4050$ & $-3.712 *$ & $1520-5067$ & $-4.265 * *$ & $2530-3040$ & $-5.178 * *$ & $4050-5060$ & $-6.692 * *$ \\
\hline & $15-5067$ & $-4.013 * *$ & $1520-67$ & $-3.778 *$ & $2530-4050$ & $-4.159 * *$ & $4050-67$ & -3.311 \\
\hline & $15-67$ & -3.386 & $2025-2530$ & $-4.551 * *$ & $2530-5060$ & $-4.471 * *$ & $5060-67$ & -3.129 \\
\hline
\end{tabular}


TABLE 3. Cointegration Analysis for Brown,Pink, White and Imported Shrimp Prices

\begin{tabular}{lccccc} 
Rank & Eigenvalue & Trace stat. & $\mathbf{5 \%}$ cv. & Max eigenvalue stat. & 5\% cv. \\
\cline { 2 - 6 } 0 & - & $117.464^{*}$ & 62.99 & $47.485^{*}$ & 31.46 \\
1 & 0.20411 & $69.979^{*}$ & 42.44 & $36.786^{*}$ & 25.54 \\
2 & 0.16210 & $33.192^{*}$ & 25.32 & $25.203^{*}$ & 18.96 \\
3 & 0.11412 & 7.9883 & 12.25 & $7.988^{*}$ & 12.52 \\
4 & 0.03768 & & & & \\
\hline
\end{tabular}

